\title{
The Student Management System Applied by Aisyiyah Rejang Lebong Creative Middle School to Improve Students' Non-Academic Achievement
}

\author{
Abdul Sahib* and Sandya Sucilarasati
}

\author{
Institut Agama Islam Negeri (IAIN) Curup, Indonesia \\ *Corresponding author. Email: abdulsahib474@gmail.com
}

\begin{abstract}
This study aims to determine how the management of students carried out at Aisyiyah Rejang Lebong Creative Middle School, the efforts of student management to improve non-academic achievement, the supporting and inhibiting factors of the implementation of student management. This qualitative research used interviews, observation and documentation for collecting the data. The Qualitative data is analysed through identification, classification, analysis, and conclusion. The results of this study indicate that student management to improve non-academic achievement starts from planning. Student admission, student organization, student orientation, student attendance, coaching and student services, student organizations, student assessment, student mutations and alumni have worked well. Supporting factors for student management in improving achievement non-academic students of Aisyiyah Creative Middle School are divided into two, namely internal encouragement (attitudes towards learning, learning motivation, concentration, storing learning outcomes, self-confidence, intelligence, habits, and the aspirations of students) and external encouragement (parents, guru or supervisor, facilities and infrastructure, social environment), while the inhibiting factors are incomplete facilities and students who are not yet disciplined.
\end{abstract}

Keywords: Student management, Non-academic achievement, Qualitative research.

\section{INTRODUCTION}

Education in general is a process of maturing individuals through life experiences. In the maturation process, individuals carry out various activities called learning experiences which shape things from thinking, moving, feeling, talking. Humans through education are simulated to think, appreciate, and act. To think and act and respect other human beings so that they can have quality, humans are required to get a higher education. Educated people are not only rich in knowledge, but also in attitudes, communication, skills and ideas that are much better. In the social sphere, they are able to adjust to society, can lead social institutions and are able to participate in social activities such as political parties and others [1].

Education is obtained in many ways, namely through the ability to learn independently and by participating in special education. And one of the most important ways to get education today is to follow formal education in elementary schools. School is an organization, which is a place to learn and a place to receive and give lessons, there are people or a group of people working together. These people include the principal, teachers and staff, students and parents or guardians of students [2].

As formal educational institutions, schools that are born and develop effectively and efficiently from and by the community are instruments that are obliged to provide services to the community in educating citizens. Schools are managed in a formal, hierarchical and chronological manner that aligns with the philosophy and goals of national education. In a school, whether it is a school that is under the auspices of the government or private, there are several elements needed in it. One of them is the element of students. Etymologically, a student is anyone who is registered as a student object in an educational institution. In the National Education System Law No. 20 of 2003 students are members of society who develop their potential through the learning process available at certain paths, levels, and types of education. Students are one of the important subsystems in the education management system in schools [1]. 
Students are a very important element for the realization of the teaching and learning process in a school. Students are a component that is very influential on all matters relating to school. One of them, students will affect the existence of a school. Students will greatly influence community interest in a school. This can be seen in terms of the achievements created by these students. This is evidenced by the number of parents who send their children to schools that have made many achievements, both in academic and nonacademic fields. Based on the things that have been stated above, the thing that is very much needed from a school is the ability to manage students, so that one of the school's goals with regard to students can be realized. Student management is one of the operational areas in school management. Student management is the arrangement of activities related to students from entering to leaving the student from a school. Student management aims to organize various activities in the field of students so that learning activities at school can run orderly, regularly, and be able to achieve school education goals [3][4].

Practically, student management will run optimally if it is managed by experts. One of the focuses of student management is how students can develop their talents and interests so that later they can make achievements. Achievement itself is a result that has been achieved after someone has done something. Achievements can be a matter of pride for both yourself and those closest to you. The achievements produced by students are not only due to the talents of students, but also due to the management of students by school personnel. The achievements of students can be in the form of academic and non-academic achievements [5][6].

Integrated Islamic Junior High School 'Aisyiyah (SMPITA) is a private school built under the organization' Aisyiyah Rejang Lebong, which is a women's organization established by Muhammadiyah Lebong. This private school was built as a form of secondary school from SDITA (Integrated Islamic Elementary School 'Aisyiyah) which has long been built with the hope that the graduates from SDITA can continue their studies to SMPITA. Based on the results of interviews conducted by the author with the student section supervisor, it was found that there were a lot of students in this Creative Junior High School who scored academic and non-academic achievements. In fact, not a few have made achievements in the field of sports at the district and provincial levels. Based on preliminary observations made by the author at 'Aisiyah Creative Middle School', the author sees that students in this school are highly accomplished. In addition to physical evidence such as trophies, evidence that students of Creative Middle School 'Aisyiyah Rejang Lebong are documents containing the achievements of students that have been achieved along with the names and branches of competitions achieved. As of 5 years since its establishment, this school has received 46 achievements by winning 1 st to 3rd place in competitions at the city, district and provincial levels [2][3].

Compared to other private madrasah, namely MTs Muhammadiyah Rejang Lebong, the achievements made by Creative Middle School 'Aisiyah are superior, this is evidenced by the achievements achieved by MTs Muhammadiyah for the past 5 years only amounting to 15 non-academic achievements. Students who have made achievements will not be given rewards in the form of money like other schools, but students will be given trophies and certificates. The author also sees that the teachers in this SMP are very maximal in managing the students' share; this is proven by the many extracurricular activities that the school offers to students to develop their talents and interests. Managing students is not an easy thing. This requires steps and proper analysis. On the other hand, 'Aisyiyah Creative Junior High School has succeeded in educating its students so that they can achieve quite a lot of achievements, especially in non-academic fields. Based on the problems described above, the author raises the title Student Management in Improving Non-Academic Achievement at Aisiyah Rejang Lebong Creative Middle School [7][8][9].

\section{METHOD}

This study aim to get an overview of the management of students in improving non-academic achievement at Creative Middle School 'Aisyiyah Rejang Lebong, the subjects in this study are:

1). The principal, the writer makes the principal as a research subject to obtain data in the form of a general description of the school in the form of history, geographic location, demographics and the education system in general.

2). Student coaches, the authors make the coaches of students as research subjects to obtain data in the form of how the coaches of students manage creative junior high school students, and the efforts of coaches of students to improve students' non-academic achievement, besides that the authors also get achievement data Non Academic students.

3). Teachers, the authors make teachers as research subjects to obtain supporting data regarding student management carried out by the school.

4). The author makes students as research subjects to obtain real data, namely whether the data submitted by the school is true with the facts applied to students. What is meant by the subject is a part of the object to be examined [4].

In this research, the author used observation, interview and documents to collect the data: 
1). Observation is used by the author to obtain data in the form of real information / real things done by the school in managing its students to increase nonacademic achievement

2). Interview is to get even more in-depth data that the writer cannot get from the results of observations, namely data on the management of students at 'Aisyiyah Rejang Lebong Creative Middle School. This interview technique is done by the writer to obtain data in the form of information that cannot be seen and obtained from observation techniques.

3). Documents obtained from this research include; Profile of 'Aisyiyah Creative Junior High School, organizational structure, state of teachers and students, vision, mission and objectives of education education, facilities and infrastructure, allocation of teaching and learning time, madrasah exam results, the role of students.

Based on the order of the problems, the writer will carry out the following steps in analyzing the research data:

1). The first step that is taken after the data is collected is identifying the data. The data obtained from the recording technique were immediately transcribed into written data. Meanwhile, data that is already in written form or notes are collected together to be identified according to the problem.

2). Classification of data, all identified data are then classified based on problems. Classification is done by classifying data based on the management aspects of students

\section{FINDING AND DISCUSSION}

How the management of students in improving non-academic achievement at Creative Middle School 'Aisyiyah Rejang Lebong is explained below:

\section{1). Planning}

Mrs. Khairani said as the Head of Creative Junior High School 'Aisyiyah, said that: "Planning here is intended to assist the school in carrying out future programs. Planning is also the basis for the school in carrying out all school activities. The planning of these students is in the form of preparation of PPDB (New Student Admission) requirements, socialization to SD about 'Aisyiyah Creative Middle School and the PPDB (New Student Admission) process. He said that: Planning for students was carried out by involving all teachers and employees of 'Aisyiyah Rejang Lebong Creative Middle School, planning was carried out looking at several aspects of the school, namely in terms of student acceptance, how students were organized, student orientation period, service and so on. other.

\section{2). Admission of students,}

The results of an interview with Mr. Henda Septian as the student representative of Creative Middle School 'Aisyiyah, he said that: The process of admitting new students at Creative Junior High School has two paths, namely achievement and selection. In the path of achievement, students are required to submit evidence of the results of their achievements such as a certificate. Furthermore, after the non-academic achievement charter has been collected, the school will also check the religious achievement of students from the value of religious subjects. If the child has a lot of achievements and has good religious scores, then the child will be accepted on the track of achievement and will no longer take the test.

\section{3). Organizing students}

The results of interviews with Mr. Meison Dwi Kurniawan as the subject teacher of Physical Education and Health, he said that: In organizing students, the school does not classify students based on their level of achievement, but the school will group students based on gender or gender, this is in accordance with the Islamic school background. This grouping of students will last from grade one to grade two. At the third grade, the grouping of students changed, that is, students would be grouped based on their level of academic achievement ability. This aims to make it easier for teachers to teach students according to their level of achievement to face the National Examination [10].

\section{4). Student orientation}

Mr. Henda Septian as the student representative explained that: In the orientation activity for 'Aisyiyah Creative Middle School students, this is called the ta'aruf period or FORTASI. In this FORTASI activity, the school was based on an Islamic school background. There is no self-humiliating activity like other public schools that are required to wear strange attribute, our school carries out useful introduction activities. The material in this activity is school regulations, school environment, school employees, and school programs, and character building. The character building is totally important since it can develop a good mannered student that appropriate with norm and moral value. Furthermore, it can make humans able to develop all their potential so that they function optimally in accordance with the rules outlined by their religion [11].

\section{5). Student attendance}

The results of the interview with Mr. Meison Dwi Kurniawan as the teacher of the 'Aisyiyah Creative Middle School' subject he said that: Student attendance activities are carried out every hour of the morning 
when after learning goes off where the picket teacher will call the class leader to submit the attendance list to that day. At the time of study, the security guard will go around the class to return to attendance for students.

Student attendance activities have been carried out properly and firmly. This activity also not only gives authority to teachers but students as well. Class leaders are given the opportunity to carry out class attendance respectively. This can train the mental leadership and honesty of students. In addition, the punishment given by the school also does not violate human rights [12].

\section{6). School guidance and services}

Mrs. Khairani as the head of the creative junior high school 'Aisyiyah said that: Guidance and services for students are carried out according to the interests and talents of students according to the results of a survey conducted by each homeroom teacher. In this case, students will be nurtured according to the interests they choose. The school leaves entirely to students regarding their interests. Usually the school that is very often associated with coaching is the counseling guidance teacher and academic advisory teacher.

\section{7). Student organizations}

Furthermore Mr. Henda Septian explained that: In public schools, student organizations are called OSIS, but at this school student organizations are called IPM, namely the Muhammadiyah Student Association under the auspices of the Muhammadiyah Foundation, this IPM is also equivalent with OSIS in public schools, so if there are regional or provincial activities organized by the government, the IPM will also be included. All students of Creative Middle School 'Aisyiyah are IPM members, represented by several students who are referred to as IPM Management with their respective fields. The way for the selection of IPM management is carried out with a democratic system, where the school will hold a general election for IPM management such as a simulation like the regional representative election.

\section{8). Student assessment.}

Based on an interview with Mr. Henda Septian as the student representative of 'Aisyiyah Creative Middle School, the whole assessment process is given to the subject teacher and homeroom teacher. The assessment process is carried out objectively, meaning that it does not only look at the academic abilities of students, but also sees the attitudes and activeness of students. This assessment process is not only carried out at the end of the semester, but at any time the subject teacher can provide an assessment to students according to the method they are carrying out. The assessment or evaluation process at 'Aisyiyah Creative Middle School is carried out objectively. Teachers not only assess students from their academic abilities, but also their daily attitudes.

In the orientation activity, motivation also given by school side to the students as a part of character building process. It is given to students due to motivation is one of the characters contained in the values of the main character of "Mandiri". Through this character, students are expected to be able solving their own problem by their selves.

\section{9). Mutations and Alumni}

The process of transfer or transfer at Creative Junior High School 'Aisyiyah only occurs between schools due to two things, namely the desire to move or be expelled from school. The mutation process in this school is the same as in other public schools. There is no difference regarding the transfer requirements for students in this school with other schools.

\section{0). Non-Academic Achievement Planning}

Mrs. Khairani as the head of 'Aisyiyah Creative Middle School' stated that: "Non-academic achievement is an achievement obtained from activities outside of course hours, or it can be called the achievement of extracurricular activities for example in the field of sports." Planning for non-academic achievement in this school starts before new prospective students enter the school year. The form of planning itself is the design of methods for coaching extracurricular activities, searching for talents and interests that begin at the time of registering new students, namely through the achievement pathway, preparing the required facilities and infrastructure and others. Mr. Meison Dwi Kurniawan stated that: "There are compulsory extracurricular activities including Tapak Suci, Pramuka, English Club, Arabic club, Tahfizh Qur'an and extracurricular options including Culinary, Arts (Choir, Painting, Music and Dance), Fashion, and Sports (Volleyball, Basketball, Futsal and Badminton)".

\section{1). Organizing students}

Based on an interview with Mr. Meison Dwi Putra as a subject teacher and coach of extracurricular activities, he revealed that: In grouping non-academic activities, the school sets limits in terms of student participation, for example in the extracurricular arrangement with only female students who are obliged to participate.

\section{2). Implementation of extracurricular activities.}

The implementation of extracurricular activities at this school is different from other schools. The extracurricular replacement system every 3 (three) 
months will make students not only master 1 (one) extracurricular field, but at least master 3 (three) extracurricular activities [13][14].

\section{3). Development of non-academic achievement}

The development of non-academic achievement is motivated by the number of guardians of students who will be more interested in enrolling their children in school who have achieved a lot, this makes the school more optimal in terms of fostering both academic and academic achievements.

\section{4). Internal supporting factors}

Attitudes towards learning from the results of the interview with Mr. Henda Septian as the student representative of 'Aisyiyah Creative Middle School,' explained that: Sometimes students' learning attitudes in extracurricular activities often change. Sometimes they are serious about practicing, sometimes they don't look serious. This is influenced by the psychological condition of students who are in transition.carried out continuously and regularly so that the talents of students are always sharp, like a knife being sharpened continuously.

\section{5). Inhibiting factors, facilities and infrastructure}

Mrs. Khairani as the head of 'Aisyiyah Creative Junior High School' explained that facilities and infrastructure are the main things that are needed in teaching and learning activities, especially in making achievements. Even today, an educational institution is considered an elite if the facilities and infrastructure are complete [15].

From the interview above, it is known that the facilities and infrastructure play an important role in scoring non-academic achievements. Because all nonacademic activities really need complete facilities and infrastructure. If the facilities and infrastructure are incomplete, then carrying out non-academic activities will also experience difficulties. The facility serves as the main part of non-academic achievement coaching activities. Because it is the main part of these activities, this tool will be very much needed for the smooth running of non-academic achievement coaching activities. Meanwhile, infrastructure has a function to support non-academic achievement activities, students, as subject teachers as well as supervisors.

\section{CONCLUSION}

After going through the process of research, study and discussion, both theoretically and empirically regarding the research, some conclusions can be drawn:
1). Student management regulates students to improve non-academic achievement, starting from student planning, student admission, student organization, student orientation, student attendance, coaching and school services, student organizations, student assessment and transfer and alumni.

2). Student management efforts to improve the nonacademic achievement of students at 'Aisyiyah Creative Middle School, namely by planning non-academic achievements starting from the acceptance stage of new students, namely through the achievement pathway, organizing students in non-academic activities, namely grouped by talent and demand who have been chosen by the students, carry out non-academic activities that change every 3 (three) months and coaching nonacademic activities.

3). Supporting factors for student management in improving the non-academic achievement of students of 'Aisyiyah Creative Middle School are divided into two, namely internal encouragement (attitudes towards learning, learning motivation, concentration, saving learning outcomes, self-confidence, intelligence, habits and ideals) and encouragement from outside (parents, teachers or coaches, facilities and infrastructure, social environment), while the inhibiting factors are infrastructure and students.

\section{REFERENCES}

[1] Abbas, Syahrizal, Higher Education Management, Jakarta: Prenada Media Group, 2008.

[2] Ali, Nizar, Islamic Education Management: An Effort to Organize Islamic Education Institutions, West Java: Pustaka Isfahan, 2009.

[3] Arifin, Islamic Education: Theoretical and Practical Overview, Jakarta: PT. Earth Literacy, 2011.

[4] Arikunto, Suharsimi, Research Management, Jakarta: Rieneka Cipta, 2004.

[5] Arsil and Maria Botifar, Education Management, Curup: LP2 STAIN, 2013.

[6] Badrudin, Student Management, Jakarta: PT Index. 2014.

[7] Dwi Anggara, Prastica, Exploration Study About Students' Academic and Non-Academic Preastation, Thesis. UNY Education Science, Wonogiri, 2015.

[8] Fathurrochman, I., \& Apriani, E. Pendidikan Karakter Prespektif Pendidikan Islam dalam Upaya Deradikalisasi Paham Radikal. Potensia: 
Jurnal Kependidikan Islam, Vol. 3(1), 122-142, 2017.

[9] Gusmuliana, P., Apriani, E., \& Karolina, A. Islamic Fefac As An Interesting Learning Media To Improve Students'english Ability And Develop Their Character Values In Man Rejang Lebong. Jurnal Inovasi Pengabdian Masyarakat Pendidikan, Vol.1(1), 36-44, 2020.

[10] Hartani, A.L, Educational Management, Yogyakarta: Laksbang Presssindo, 2011.

[11] Kendiani, S. D. The Islamic Characters in Teaching English. Journal of English Education and Teaching, Vol.4, 431-448, 2020.
[12] Imron, Ali, School-Based Student Management, Jakarta: Bumi Aksara, 2012.

[13] J Moelong, Leksi, Qualitative Research Methods, Bandung: Rosda Karya, 2002.

[14] Mahfud, Agus, Islamic Education: Gus Dur's Thought, Yogyakarta: Nadi Pustaka, 2012.

[15] Marno, Management and Leadership of Islamic Education, Bandung: PT. Refika Aditama, 2013. 